\title{
Suomalaisen kasvatustutkimuksen kvalitatiivinen menetelmäkirjallisuus
}

\author{
Laadullisen tutkimuksen \\ menetelmakiriallisuudessa ei \\ ohjata riittãvästi kootun aineiston \\ analyysiin, tulkintojentekoon ja \\ arviointiperusteisiin. \\ Saatavilla oleva suomenkielinen \\ menetelmátieto on lisáksi palasina \\ ja hahmotelmina. "Kokonaisesitys \\ puuttuu edelleen", Juha Suoranta \\ toteaa laadullisen tutkimuksen \\ suomenkielisen kirjallisuuden \\ arviossaan.
}

Vaikka erilaisia kvalitatiivisia menetelmiä käytetään nykyään runsaastikin erilaisissa kasvatustutkimuksissa, alan suomenkielistä metodikirjallisuutta ei ole kovinkaan paljon tarjolla. Tutkimuskäytänteissä on tapahtunut muutos, mutta uusia metodioppaita ei ole vielä kirjoitettu. Suomalaisesta laadullisten menetelmien kokonaisesityksestä on suorastaan pulaa.

Rinne (1988, 131-132) kuvaa kasvatustieteiden historiallista kehitystä kolmena tieteellisen aikakauden eli paradigman vaihdoksena. Hegeliläisestä paradigmasta siirryttiin herbartilaiseen, ja herbartilaisesta empiiriseen. Empiirisestä paradigmasta ollaan nyt siirtymässä fenomenologiseen tai hengentieteelliseen. Kehitys on siis kulkenut filosofis-teologisesta ajattelusta tiukan empiristisen, luonnontieteitä mallittavan tutkimuksen kautta uuteen fenomenologis-hermeneuttiseen ajatteluun. Uudempi fenomenologis-hermeneuttinen ajattelu eroaa eräässä suhteessa aiemmasta, 1800luvulla vallinneesta. Nykyisessä hengentieteellisessä suuntauksessa on leimallista pyrkimys yhdistää filosofisluonteinen ajattelu ja tulkinnallinen empiirinen tutkimus.
Esitetyn hahmotelman ongelmallisuus on siinä, että sen mukaan empiirinen paradigma olisi kumoutumassa yksittäistapausten ja yksilöiden empiiriseen tutkimukseen virittäytyneellä hengentieteellisellä paradigmalla. Ylipäätään paradigman käsite on ongelmallinen kuvaamaan maamme kasvatustieteiden, varsinkin toisen maailmansodan jälkeistä kehitystä. Pikemminkin kuin paradigman vaihdoksina, jotka edellyttävät $\mathrm{mm}$. edellisen paradigman totuuksien vääjäämätöntä kumoutumista uusilla, näyttäisi kasvatustieteiden kehitys olleen sekä teoreettisten että metodisten mahdollisuuksien monipuolistumista.

Kasvatustutkimus ei ole monipuolistunut ainoastaan teoreettisilta lähestymistavoiltaan, vaan myös tutkimusmenetelmällisesti. Menetelmien osalta ei suinkaan ole käynyt niin, että jotkut (kvalitatiiviset) menetelmät olisivat syrjäyttäneet tai olisivat syrjäyttämässä jotkut muut (kvantitatiiviset).

90-luvun alussa näyttää siltä, että kasvatustieteiden tutkimusmenetelmävalikoimassa on tapahtunut ekspansio. Opinnäytteitä tehdään yhä enemmän kvalitatiivisin menetelmin (Syrjälä 1991). Selvitysten (Tynjälä ym. 1991) mukaan myös monien menetelmien yhteiskäyttö, metodinen eklektismi, on suosiossa. Enemmänkin näyttää siis käyneen niin, että kvalitatiiviset menetelmät ovat ikään kuin hiipineet kasvatustieteiden tutkimuskäytäntöihin.

Tilanteen muutosta olisi paradigmavaihdoksen sijasta mielekästä ajatella eräänlaisena syklinä tai aaltoliikkeenä. Asian vertauksena voi käyttää kuvitteellista tutkimusmenetelmien ensyklopediaa. Aika ajoin joidenkin sivujen lukeminen on paljon kiinnostavampaa kuin joidenkin toisten. Joskus taas ne sivut, joita nyt vain huolimattomasti selaillaan, muuttuvat kiinnostaviksi. 


\section{Mikä on uutta?}

Laadullisten tutkimusmenetelmien uutuus on kovin suhteellinen asia. Pikemminkin kuin kvalitatiivisen tutkimuksen uutuudesta, olisi kenties puhuttava kvalitatiivistyyppisten tutkimusmenetelmien uudesta tulemisesta suomalaiseen kasvatustutkimukseen. Tähän käsitykseen pääsee lueskelemalla joitakin suomalaisen kasvatustieteen klassisia kirjoituksia. Esimerkiksi Albert Lilius esittelee teoksessaan Kasvavien tunne-elämä (1927) kokeellisten menetelmien ohella sellaisia empiirisiä menetelmiä, joita nykyisin nimitettäisiin laadullisiksi.

Havainnoinnin Lilius jakaa itsehavainnointiin (introspektioon ja retrospektioon) ja toisten havainnointiin (ekstrospektioon). Havainnoinnin lisäksi Lilius nostaa tutkimusaineistoina esiin kasvavien erilaiset tuotokset kuten runot, kirjeet, päiväkirjat ja piirustukset. Psykoanalyyttisen menetelmän esittelyn yhteydessä viitataan vapaiden mielleyhtymien menetelmän ohella elämänkertojen ja kaunokirjallisten tuotteiden käyttöön tutkimusmateriaaleina. Mikä on uutta? Tämän päivän menetelmäkeskustelujen kannalta on opettavaista lukea Liliuksen metodologista huomautusta:

"On olemassa sielutieteellinen suunta - amerikkalainen behaviorismi - joka tahtoo nojautua niin paljon kuin mahdollista ainoastaan objektiiviseen ekstrospektioon, t.s. se karttaa ekstrospektiivisesti todetun tulkitsemista täydentävän itsehavainnon avulla. Minä liityn niihin, jotka pitävät tulkitsemisyrityksiä luvallisina ja välttämättöminä" (emt., 184)

\section{Laadullisten menetelmien suomalaiset klassikot}

Laadullisten menetelmien opetuksen laajentuessa ongelmaksi tulee käytettävissä olevan oppimateriaalin niukkuus. Kvalitatiivisen tutkimuksen eri puolia esittelevät monografiat, Martti Grönforsin Kvalitatiiviset kenttätyömenetelmät(1982) sekä Sirkka Hirsjärven ja Helena Hurmeen Teemahaastattelu (1980), ovat iästään huolimatta kiistämättömän ansiokkaita ja ansaitsevat, valikoiden lukemalla, edelleen paikkansa alan perusteoksina.

Yleisesityksellisyydestään huolimatta myös Kari Niinistön teos Inhimillistä toimintaa tarkasteleviin tieteisiin ja erityisesti kasvatustieteelliseen tutkimukseen soveltuvat tulkinnallisen paradigman- mukaiset tutkimusmallit ja -menetelmät (1981) on lunastanut paikkansa suomalaisen kasvatustutkimuksen laadullisen linjan pioneerityönä. Kirja on kuulunut vuosien ajan useiden kvalitatiivisen tutkimuksen menetelmäkurssien tenttikirjallisuuteen.

Metodiopetuksen kannalta em. kirjoja voi varauksin pitää maamme laadullisen tutkimuksen klassikkoina, joihin, kuten muuhunkin menetelmäkirjallisuuteen, on sanomattakin syytä suhtautua asian vaatimalla kriittisyydellä.

\section{Menetelmäoppaiden erittelyä}

Sivuan seuraavassa tarkasti ottaen vain kasvatustutkimuksen kvalitatiivisia menetelmäoppaita. Rajaus ei tarkoita sitä, että sana kasvatus, metoditeosten määreenä, mitenkään muuten rajaisi teosten käyttöalaa. Yhtä hyvin kuin toisin päin, saattavat myös kasvatustutkimuksen menetelmäpohdinnat ja -innovaatiot hyödyttää esimerkiksi sosiaalitieteilijöitä. Sosiologian yhteydessä ilmestyneitä oppaita (esimerkiksi Mäkelä 1990) ei ole tarkoituksenmukaista ottaa tässä huomioon, näkökulma kun on kasvatustieteellinen.

Rajaan tarkastelustani myös sellaiset tutkimuksen yleistä metodologiaa käsittelevät teokset (esimerkiksi Olkinuora 1988), yhden asian liikkeet (esimerkiksi Siljander 1988) ja yksittäiset tutkimukset (esimerkiksi Syrjäläinen 1990), joissa alaa saatetaan koota yhteen laajastikin, mutta jotka eivät suoraan tarjoa opetuksia kvalitatiivisen tutkimuksen käsityötaidoista. Rajaus on ongelmallinen kahdessakin mielessä. Ensinnäkin, nyt esillä olevat teokset sisältävät myös metodologista pohdintaa. Toiseksi rajaus palvelee tekstini jäsennystä, eikä noudattele tutkimuskäytänteiden logiikkaa. Parhaimmillaan laadulliset tutkimuskäytänteet ovat nimittäin empiiristen havaintojen ja teoreettisten näkökulmien hedelmällistä vuoropuhelua.

Kolmesta kasvatustutkimuksen laadullisia tutkimusmenetelmiä esittelevästä teoksesta kaksi on artikkelikokoelmia. Kokoomateoksilla on omat hyvät ja huonot puolensa. Artikkelikokelma antaa laadullisen tutkimuksen eri lähestymistavoista monipuolisen kuvan. Kokoelmat ovat kuitenkin epäyhtenäisiä sekä laadultaan että sisällöiltään. Paradoksaalisesti niiden vaikeus käytännön tutkimukseen johdattavina oppaina on vaihtoehtojen runsaudessa: on olemassa monia mahdollisuuksia tehdä laadullista tutkimusta, mutta jostain pitäisi saada kiinni. 
Kaksi esillä olevista julkaisuista on ilmestynyt yliopistojen laitossarjoissa (Syrjälä \& Numminen 1988; Syrjälä \& Merenheimo 1991), yksi kaupallisen kustantajan toimesta (Gröhn \& Jussila 1992). Siinä mielessä, että kvalitatiivisista menetelmistä ylipäätään julkaistaan esityksiä, voidaan kai puhua kulttuuriteoista. Kulttuuriteoista toivoisi voivansa puhua myös julkaisujen sisältöjen suhteen. Pelkästään menetelmäkirjallisuuden pieni määrä ei liene peruste julkaista menetelmistä mitä sattuu.

Terttu Gröhnin ja Juhani Jussilan toimittama Laadullisia läbestymistapoja koulutuksen tutkimuksessa (1992) on sisällöltään varsin epäyhtenäinen. Kirja on alunperin syntynyt Helsingin yliopiston kasvatustieteilijöiden jatkokoulutusseminaarin esitysten pohjalta. Mitään pois jättämättä, korjaamatta tai uudistamatta, kirjaa tarjotaan nyt laajemmalle lukijakunnalle. Kumpaakohan ovat julkaisupäätöstä tehdessään miettineet, määrää vai laatua?

Kirjassa on kuusi artikkelia, joista varsinaisesti neljässä esitellään menetelmiä, kaksi on enemmän tapauskertomuksenomaisia menetelmäsovelluksia. Laadullisista menetelmistä ovat esillä Ference Martonin tutkijaryhmineen kehittämä fenomenografinen tutkimusote (Gröhn), pehmeää systeeminen metodologia (Kauppi), diskurssianalyysi (Lindroos) ja systemaattinen metodologia (Jussila, Montonen ja Nurmi). Kahdesta menetelmäsovelluksesta toisessa Erkki Auvinen esittelee tutkimustaan, jonka tavoitteena oli selvittää työntekijöiden selviytymistä eräistä paperikoneen ohjaustoiminnoista. Toisessa teelmässä Kirsti Launis selvittää eräällä henkilöstökoulutuskurssilla järjestettyä tutkimusta.

Kun kysymyksessä on laadullista otetta esittelevä menetelmäkirja, olettaisi menetelmäsovellutuksiltakin enemmän tutkimuksellista problematisointia. Auvisen ja Launiksen kirjoituksien pääosissa ovat kuitenkin paperikoneenhoitajat, konelinjamiehet ja toksilogit, kun tarkoitus oli puhua menetelmistä. Ritva Lindroosin diskurssianalyysiartikkeli jää valitettavasti harjoitelman asteelle. Tutkimusmenetelmällisessä mielessä painavinta ja ajallisesti kestävintä tekstiä ovat kirjoittaneet $J u$ bani Jussila, Kaisu Montonen ja Kari E. Nurmi esittelemällä systemaattista analyysia kasvatustieteiden tutkimusmenetelmänä. Samoin Antti Kaupin ja Terttu Gröbnin tekstit valottavat laadullisen tutkimuksen erityyppisiä mahdollisuuksia.

Leena Syrjälä ja Jubani Merenbeimo ovat toimittaneet Oulussa pidetyistä kvalitatiivisten tutki- musmenetelmien seminaariesitelmistä kootun kirjasen Kasvatustutkimuksen laadullisia lähestymistapoja (1991). Muutamien metodologisten pohdintojen lisäksi (Lehtinen; Karjalainen) artikkeleissa esitellään melko laajasti erilaisia laadullisen tutkimuksen lähestymistapoja. Toisaalta käsitellään toimintatutkimusta (Kurtakko) ja kouluetnografiaa (Syrjäläinen), toisaalta grounded theory -lähestymistapaa (Rostila) ja fenomenografiaa (Uljens). Pentti Moilanen tarkastelee tulkinnan ja todentamisen kysymyksiä hermeneuttisen kasvatustutkimuksen perspektiivistä. Kirjan loppu on täytetty joidenkin Oulun yliopiston jatkotutkintoa suorittavien opiskelijoiden alustuksilla omista tutkimushankkeistaan.

Artikkelikokoelman ansio on sen laajassa tarkastelukulmassa. Kasvatustieteen kannalta tärkeitä ovat toimintatutkimuksen ja kouluetnografisen tutkimuksen esittelyt. Varsinkin jälkimmäistä meillä on tehty vähän. Samoin tulkinnan ja todentamisen kysymyksiin perehtyvä kirjallisuus on laadullisen tutkimuksen kehittämisen kannalta merkittävä. Kuten kirjassakin annetaan ymmärtää (Syrjälä), kvalitatiivisen tutkimuksen tärkeimpiä haasteita on kehittää aineiston analyysitapoja ja selkeyttää analyysin arviointia.

Leena Syrjälän ja Merja Nummisen Tapaustutkimus kasvatustieteessä (1988) on kahdesta jäljessä tulevasta poiketen monografia. Tapaustutkimus on kirjoittajille sateenvarjokäsite, jonka alla tehdään monenlaista tutkimusta. Tutkimusten yhteisiä piirteitä ovat 1) osallistujien näkökulma, 2) keskittyminen pieneen tapausmäärään ja 3) nykyisyyden todelliseen tilanteeseen. Lisäksi tapaustutkimuksessa ilmiöitä tutkitaan ns. luonnollisissa ympyröissä strukturoimattomilla menetelmillä. Laadullista tutkimusta tekijät eivät yleisnimenä käytä, sillä tapaustutkimuksissa on mahdollista kerätä myös kvantitatiivista tietoa.

Raportissa pyritään kattavaan esitykseen laadullisista tutkimuskäytänteistä. Tässä tavoitteessa on onnistuttu kohtuullisen hyvin. Tämän oppaan avulla luulisi olevan mahdollista tehdä kelvollista kvalitatiivista tutkimusta. Kirjan ansio on myös siinä, että se on suhteellisen ehyt ja systemaattisesti etenevä kokonaisuus. Sen avulla pääsee helposti eteenpäin laadullisen tutkimuksen joskus mutkikkailla polulla. Kirjan kirjoittajat ovat selvästi hyödyntäneet synenergiaa kirjan päämääriä palvelevalla tavalla. Erilaisten tapaustutkimusten ja tutkimusaineistojen esittely korostuu kirjassa. Sen sijaan tutkimusaineiston analysointi, tulkinta ja raportointi jäävät vähemmälle huomiolle. 
Miten laadulliseen tutkimukseen kannattaisi alkaa perehtyä, jos valittavana olisivat em. teokset. Vaikka tarkoitus ei ole panna kirjoja paremmuusjärjestykseen, itse aloittaisin Syrjälän ja Nummisen kirjasta Tapaustutkimus kasvatustieteessä. Se on johdonmukainen esitys verrattuna kahteen muuhun. Seuraavaksi lukisin Kasvatustutkimuksen laadullisia lähestymistapoja (Syrjälä \& Merenheimo 1991) ja vasta viimeisenä Laadullisia lähestymistapoja koulutuksen tutkimuksessa (Gröhn \& Jussila 1992), senkin valikoiden.

\section{Parempia aikoja odotellessa}

Miltä kasvatustutkimuksen kvalitatiivisen menetelmäkirjallisuuden tila näyttää esiteltyjen teosten valossa? Tiivistetysti sanottuna aineiston keräyksestä, lähestymistavoista ja jonkin verran metodologiasta on kirjoitettu, mutta jotain puuttuu. Muiden ohella Sirkka Hirsjärvi (1991) on Kasvatus-lehden laadullisten menetelmien teemanumerossa kiinnittänyt huomiota siihen, että kvalitatiivisia haastatteluja tehdään mielellään, aineistoja kerätään innostuneesti, mutta vaikeudet alkavat tämän jälkeen. Näistä vaikeuksista, aineiston analyysista, tulkinnasta ja arviointiperusteista, ei juuri ole kirjoitettu.

Laadullisin menetelmin koottujen aineistojen analyysi-, tulkinta- ja arviointiperusteiden vaihtoehtoja erittelevän kirjallisuuden puute on toisaalta ymmärrettävää, toisaalta hämmästyttävää. Analyysimenetelmäksi ei riitä tutkijan omaan intuitioon perustuva analysointi eivätkä ns. impressionistiset tai journalistiset tekniikat, tarvitaan muutakin. Muuta on vielä tällä hetkellä etsittävä ulkomailta, josta menetelmälliset vaikutteet virtaavat muutenkin maahamme.

Toinen kotimaisen kvalitatiivisen menetelmäkeskustelun puute on se, että paloja ja hahmotelmia kyllä on, mutta esimerkiksi menetelmäopetuksessa käyttökelpoista kokonaisesitystä ei ole tarjolla. Voidaan tietysti kysyä tarvitaanko kokonaisesitystä tai onko se laadullisten menetelmien luonteesta johtuen edes mahdollinen. Parempia aikoja odotellessa on tyydyttävä ulkomaisiin laadullisen tutkimuksen oppaisiin, joista löytyy kohtuullisen onnistuneita kokonaisesityksiä (esimerkiksi Strauss 1987; Patton 1990) - miksei sellaista olisi mahdollista kirjoittaa suomeksikin.

\section{LÄHTEET}

Gröhn, T. \& Jussila, J. (toim.) 1992. Laadullisia lähestymistapoja koulutuksen tutkimukseen. Helsinki: Yliopistopaino.

Grönfors, M. 1982. Kvalitatiiviset kenttätyömenetelmät. Juva: WSOY.

Hirsjärvi, S. \& Hurme, H. 1980. Teemahaastattelu. Gaudeamus.

Hirsjärvi, S. 1991. Kvalitatiivisesta tutkimuksesta ja tutkimuksen ohjauksesta. Kasvatus 22 (5-6), 363-364.

Lilius, A. 1927. Kasvavien tunne-elämä. Suom. A. Oksala ja J. Timonen. Porvoo: WSOY.

Mäkelä, K. (toim.) 1990. Laadullisen aineiston analyysi ja tulkinta. Helsinki: Gaudeamus.

Niinistö, K. 1981. Inhimillistä toimintaa tarkasteleviin tieteisiin ja erityisesti kasvatustieteelliseen tutkimukseen soveltuvatulkinnallisen paradigman mukaiset tutkimusmallit ja -menetelmät. Turun yliopiston kasvatustieteiden tiedekunnan julkaisuja A: 85.

Olkinuora, E. (toim.) 1988. Yleispätevää ja lainalaista etsimässä: metodologisia mietteitä. Turun yliopiston kasvatustieteiden tiedekunnan julkaisuja B: 27.

Patton, M. Q. 1990. Qualitative evaluation and research methods. Newbury Park: Sage.

Rinne, R. 1988. Kasvatustieteen tiedetradition vaikutus olemassa olevaan tutkimuskäytäntöön. Teoksessa Immonen, K. (toim.) Tieteen historia - tieteen kritiikki. Turun yliopiston historian laitos. Julkaisuja n:o 19. Turku, 119-137.

Siljander, P. 1988. Hermeneuttisen pedagogiikan pääsuuntaukset. Oulun yliopiston kasvatustieteiden tiedekunnan tutkimuksia 55.

Strauss, A. L. 1987. Qualitative analysis for social scientists. New York: Cambridge University Press.

Syrjälä, L. \& Merenheimo, J. 1991. Kasvatustutkimuksen laadullisia lähestymistapoja. Oulun yliopiston kasvatustieteiden tiedekunnan opetusmonisteita ja selosteita 39.

Syrjälä, L. \& Numminen, M. 1988. Tapaustutkimus kasvatustieteessä. Oulun yliopiston kasvatustieteiden tiedekunnan tutkimuksia 51.

Syrjälä, L. 1991. Kvalitatiivinen kasvatustutkimus Suomessa. Teoksessa Syrjälä, L. \& Merenheimo, J. (toim.) Kasvatustutkimuksen laadullisia lähestymistapoja. Oulun yliopiston kasvatustieteiden tiedekunnan opetusmonisteita ja selosteita 39, 2-10.

Syrjäläinen, E. 1990. Oppilaiden ja opettajan roolikäyttäytyminen luokkahuoneyhteisössä. Etnografinen tapaustutkimus peruskoulun ja steiner-koulun ala-asteen 4. luokalta. Helsingin yliopiston opettajankoulutuslaitos, tutkimuksia 78.

Tynjälä, P. \& Kemppainen, J. \& Nieminen, S. 1992. Mitä tutkimusrekisteri kertoo suomalaisesta kasvatuksen tutkimuksesta? Kasvatus 23 (2), 158-169. 